\title{
Assessing the Influence of Climate Extremes on Ecosystems and Human Health in Southwestern Amazon Supported by the PULSE-Brazil Platform
}

\author{
L. E. O. C. Aragão1,2* , J. A. Marengo 3 , P. M. Cox ${ }^{4}$, R. A. Betts ${ }^{4,5}$, D. Costa ${ }^{4}$, N. Kaye ${ }^{5}$, L. Alves ${ }^{6}$, \\ L. T. Smith7 , I. F. A. Cavalcanti' ${ }^{8}$, G. Sampaio ${ }^{6}$, L. O. Anderson ${ }^{3}$, M. Horta ${ }^{9}$, S. Hacon ${ }^{9}$, \\ V. L. Reis ${ }^{10}$, P. A. M. Fonseca11, I. F. Brown'12 \\ ${ }^{1}$ Divisão de Sensoriamento Remoto/Instituto Nacional de Pesquisas Espaciais (DSR/INPE), São Jose dos Campos, \\ São Paulo, Brazil \\ ${ }^{2}$ College of Life and Environment Sciences, University of Exeter, Exeter, UK \\ ${ }^{3}$ Centro Nacional de Monitoramento e Alertas aos Desastres Naturais (CEMADEN), São Jose dos Campos, \\ São Paulo, Brazil \\ ${ }^{4}$ College of Engineering, Mathematics and Physical Sciences, University of Exeter, Exeter, UK \\ ${ }^{5}$ Met Office Hadley Centre, Exeter, UK \\ ${ }^{6}$ Centro de Ciências do Sistema Terrestre/Instituto Nacional de Pesquisas Espaciais (CCST/INPE), Sao Jose dos \\ Campos, Sao Paulo, Brazil \\ ${ }^{7}$ School of Geographical Sciences, University of Bristol, Bristol, UK \\ ${ }^{8}$ Centro de Previsão de Tempo e Estudos Climáticos/Instituto Nacional de Pesquisas Espaciais (CPTEC/INPE), \\ São José dos Campos, São Paulo, Brazil \\ ${ }^{9}$ National Institute of Public Health/Oswaldo Cruz Foundation (FIOCRUZ)/ENSP, Rio de Janeiro, Brazil \\ ${ }^{10}$ Secretaria de Estado de Meio Ambiente-Sema, Prefeitura do Acre, Rio Branco, Brazil \\ ${ }^{11}$ Instituto Nacional de Pesquisas da Amazônia (INPA), Manaus, Brazil \\ ${ }^{12}$ Universidade Federal do Acre, Rio Branco, Brazil \\ Email: "laragao@dsr.inpe.br
}

Received 14 June 2016; accepted 3 September 2016; published 6 September 2016

Copyright (C) 2016 by authors and Scientific Research Publishing Inc.

This work is licensed under the Creative Commons Attribution International License (CC BY).

http://creativecommons.org/licenses/by/4.0/

(c) (i) Open Access

\section{Abstract}

The complexity of multi-dimensional climate, environmental and human health information complicates bringing together scientists, civil society, and decision makers to provide adequate mitigation and adaptation options for the consequences of global environmental change. To provide an effective pathway to conciliate (integrate) these datasets, we present PULSE-Brazil as the Plat-

\footnotetext{
${ }^{*}$ Corresponding author.

How to cite this paper: Aragão, L.E.O.C., Marengo, J.A., Cox, P.M., Betts, R.A., Costa, D., Kaye, N., Alves, L., Smith, L.T., Cavalcanti, I.F.A., Sampaio, G., Anderson, L.O., Horta, M., Hacon, S., Reis, V.L., Fonseca, P.A.M. and Brown, I.F. (2016) Assessing the Influence of Climate Extremes on Ecosystems and Human Health in Southwestern Amazon Supported by the PULSEBrazil Platform. American Journal of Climate Change, 5, 399-416. http://dx.doi.org/10.4236/ajcc.2016.53030
} 
form for Understanding Long-term Sustainability of Ecosystems and human health. The overarching aim of this paper is to focus on two study cases in the Brazilian state of Acre, 1) analyzing recent socio-environmental disasters such as the impacts of droughts and consequent increases in fire detections on the incidence of respiratory diseases, and 2) evaluating the impacts of temperature increases in combination with rainfall seasonality upon the incidence of Dengue fever. Based on data available in PULSE-Brazil platform, we also aim to provide insights on the consequences of future climate variability on ecosystems and human health. Finally, we provide a discussion on the collaborative process between scientists and policymakers that defined the PULSE-Brazil platform specifications and datasets and propose a conceptual pathway for promoting the interaction between science and policy during the process of producing a tool that allows the understating of climate-relate processes. Our results clearly demonstrated that ecosystems are under increased fire risk in the future that will, in turn, affect the health of human populations. Moreover, humans are also exposed to critical Dengue fever outbreaks with the projected increase in minimum temperatures. Therefore, minimizing the impacts of these potentially ascending socio-environmental problems is the first step for adapting to a changing climate in the Amazon region. We expect that PULSE-Brazil will serve not only as a technical tool for supporting governance, management, mitigation and long-term adaptation plans for climate impacts and natural disasters, but also will take advantage of its graphical capabilities to be an instructive vehicle that facilitates information flow for societal governance.

\section{Keywords}

Amazon, Droughts, Human Health, Fire, Climate Change, Vulnerability, Adaptation, Natural Hazard

\section{Introduction}

Bringing together scientists, civil society and decision makers in an effort to provide the best mitigation and adaptation options for the consequences of planetary environmental changes is not trivial. In Amazonia, however, the recent occurrence of two major droughts and four floods from 2005 to 2015, related to natural climate variability [1]-[9] reinforced the need for such orchestrated societal action. These droughts and floods, have affected humans and natural systems, by increasing direct infrastructural losses, frequency of forest fires and risk of diseases. These socio-environmental disasters were particularly critical in the Amazonian state of Acre, which has suffered with these climatic extremes since 2005 [6]-[8] [10] [11], increasing the need for planning ahead adaptation solutions to climate change and improving the understanding on the risk of natural disasters in all their dimensions from exposure to vulnerabilities. The United Nations, under the Hyogo Framework for Action 2005-2015 [12] and the Sendai Framework for Disaster Risk Reduction 2015-2030 [13], recognized the need for an agreement that enforces and shares responsibility to reduce the risk of natural disasters by states, local governments, private sector and other stakeholders. The international scientific community is developing a greater understanding of the underpinning science and the associated impacts of climate change in Amazonia. The challenge now, however, is to continue developing the science while at the same time engaging with the national and international stakeholders, the key policymakers and the local communities, particularly in developing countries. One critical constraint for policymakers to expand regional understanding for developing mitigation and adaptation policies and cope with present and future effects of climate perturbations is the complexity of climate and environmental data [14].

As conciliating natural science's knowledge with social, economic and governance processes has, in the last decade, been recognized as an important step towards a sustainable society [15], a wide range of software and modeling technologies are being developed as tools for providing science-based information for policy and planning activities [16] [17], in the quest of supporting policymakers globally. Examples of these technologies are available at the Climate Change Knowledge Portal from the World Bank (http://sdwebx.worldbank.org/climateportal/index.cfm), the Ecosystem-Based Management Tools Network (https://www.ebmtoolsdatabase.org/resource/climate-change-vulnerability-assessment-and-adaptation-tools), the United Nations Framework Convention on Climate Change [18] and studies such as [17]. Currently, there is a 
lack of tools with readily available multi-dimensional datasets able to synthesize information on climate, environment and human health in a comprehensive arrangement, enabling different sectors to understand the consequences of extreme events and to propose well-grounded and timely decisions. To overcome this gap, a complimentary tool, specifically designed for Brazil, PULSE-Brazil (Platform for Understanding Long-term Sustainability of Ecosystems and Health-http://www.pulse-brasil.org) is being developed following a rational of collaborative production (co-production) process, which is based on some critical understanding of key system parameters and practical policymakers need by scientists. PULSE-Brazil is a UK-Brazil jointly initiative, focused on the implementation of a web platform aimed to provide general level knowledge in the form of maps and basic time-series graphics on the impacts of climate extremes on ecosystems and human health in Amazonia. This initiative is in line with the Sendai Framework for Disaster Risk Reduction 2015-2030 [13], which explicitly recognizes the need of the risk-informed decision making based on the open exchange of data and information in a platform. PULSE-Brazil is based on strong long-term links between Brazilian and UK scientists, with crossdisciplinary expertise including environmental, human health and modeling backgrounds and their close relationship with Brazilian stakeholders and policymakers [14].

Therefore, the overarching aim of this paper is to focus on two study cases in the Brazilian state of Acre, 1) analyzing recent socio-environmental disasters such as the impacts of droughts and consequent increases in active fire detections on the incidence of respiratory diseases, and 2) evaluating the impacts of temperature increases in combination with rainfall seasonality upon the incidence of Dengue fever. Based on data available in the PULSE-Brazil platform, we also aim to provide insights on the consequences of future climate variability on ecosystems and human health. Finally, we provide a discussion on the collaborative process between scientists and policymakers that defined the PULSE-Brazil platform specifications and datasets and proposed a conceptual pathway for promoting the interaction between science and policy during the process of producing a tool that allows the understating of climate-relate processes.

\section{Materials and Methods}

\subsection{Datasets}

PULSE-Brazil has been designed to be a scientific-based platform to 1) build understanding and awareness of climate variability and change, as well as its impacts on society; 2) inform policy and engage with stakeholders; and 3) provide data to allow the development of independent adaptation and risk management strategies. PULSE-Brazil was conceived by the Brazilian National Institute for Space Research (INPE), the National Center for Monitoring and Early Warning of Natural Disasters (CEMADEN), the University of Exeter, the UK Met Office, and the National Institute of Public Health (FIOCRUZ_Fundacão Oswaldo Cruz). PULSE-Brazil is being implemented by scientists following insights from Acre government officials, which have identified main climate problems for the region, have provided observational local data, and have provided an open and multistakeholder dialogue for understanding their environmental and health governance agenda and identifying their main actors and their short to middle term policymaking goals. This interaction created a unique opportunity to undertake the co-production of environmental information with interested stakeholders to provide readily-available data (Table 1) in a user-friendly way, combining clear visualization and simple graphical tools. The association of climate extremes with flooding and droughts with human health risks as a consequence of subtle shifts in the hydrological cycle and fire occurrence were the two key processes indentified by stakeholders. In the following sections we formalize the methods and results of the pilot study in Acre state using information provided by the PULSE-Brazil platform.

\subsection{Analyses}

To achieve our specific aims and exemplify the potentiality of the datasets provided by PULSE-Brazil as well as the graphic capabilities for understanding the interactions between climate, ecosystems and human health, we proposed to evaluate two study cases in the Amazonian State of Acre, a region of 152,581.4 $\mathrm{km}^{2}$ situated in the southwest of the Brazilian Amazon: 1) the impact of fires on respiratory diseases, and 2) the influence of minimum temperature on Dengue fever outbreaks. To explore future scenarios for study cases 1 and 2, in order to subsidize decision maker's actions, we also evaluated CMIP5 projections of rainfall and minimum temperature. 
Table 1. Summary of PULSE-Brazil datasets and current implementation status.

\begin{tabular}{|c|c|c|c|}
\hline \multirow{2}{*}{ Datasets } & \multicolumn{3}{|c|}{ Data description } \\
\hline & Characteristics & Status & Source \\
\hline Climate observations & $\begin{array}{l}\text { National level maps of temperature and } \\
\text { precipitation anomalies, at } 1^{\circ} \times 1^{\circ} \text { degree } \\
\text { spatial resolution data from } 1929 \text { to } 2012 \text {. }\end{array}$ & implemented & $\begin{array}{c}\text { Climatic Research Unit (CRU } \\
\text { TS 3.21) }\end{array}$ \\
\hline $\begin{array}{l}\text { Climate projections from global } \\
\text { climate models }\end{array}$ & $\begin{array}{l}\text { Decadal average maps for temperature, } \\
\text { precipitation and runoff anomalies from } \\
\text { the 2010s to the 2090s in relation to the } \\
1961 \text { to } 1990 \text { baseline period. }\end{array}$ & implemented & $\begin{array}{l}\text { CMIP5 archive from IPCC } \\
\text { 5th Assessment }\end{array}$ \\
\hline River level datasets & $\begin{array}{l}\text { Data from fluvial stations for the Brazilian } \\
\text { state of Acre, covering the past } 40 \text { years }\end{array}$ & implemented & Acre’s government datasets \\
\hline Health data & $\begin{array}{l}\text { Regional hospitalization data for malaria, } \\
\text { Dengue, diarrhea, leptospirosis and } \\
\text { respiratory diseases over the Brazilian } \\
\text { state of Acre. }\end{array}$ & implemented & $\begin{array}{l}\text { Brazilian Unified Health } \\
\text { System }\end{array}$ \\
\hline Active fire data & $\begin{array}{l}\text { National level location of active fires from } \\
\text { the TERRA and AQUA satellites. }\end{array}$ & Under development & $\begin{array}{l}\text { MODIS collection } 5 \text { Global } \\
\text { Monthly Fire Product } \\
\text { (MCD14ML) }\end{array}$ \\
\hline Aerosol optical depth & $\begin{array}{l}\text { National level maps of ambient aerosol } \\
\text { optical thickness over the Brazilian } \\
\text { continent at } 1^{\circ} \times 1^{\circ} \text { degree spatial } \\
\text { resolution. }\end{array}$ & Under development & $\begin{array}{l}\text { Level-3 MODIS Atmosphere } \\
\text { Monthly Global Product } \\
\text { (MOD08_M3) }\end{array}$ \\
\hline
\end{tabular}

\subsubsection{Fires and Respiratory Diseases}

To assess the impact of drought-associated fires on respiratory diseases for inhabitants under-five years of age in Acre state, direct age standardized rates (ASR) for hospitalizations were calculated (Appendix) using the data downloaded from the PULSE-Brazil platform. This dataset was analyzed in combination with rainfall (mm), number of active fires, and aerosol optical depth (adimensional) data. The latter two variables are being prepared to be incorporated into the system. The individual datasets were plotted against time to detect if prominent anomalous signals were observed during the peak of the drought compared with the ten-year-mean. A linear regression analysis was carried out for each variable against the ASR. As health data is in count format and do not follow a Gaussian distribution, we also modeled the incidence of respiratory diseases as a function of environmental variables using a Poisson regression method [19]. However, to account for over dispersion of count data [20], leading to an underestimation of the standard errors and overstating the significance of the parameter estimates, we used the quasi-Poisson regression model.

\subsubsection{Temperatures and Dengue Fever Outbreaks}

To test the impact of temperature on Dengue fever outbreaks we first produced spatially explicit maps of Dengue fever for the 12 months of 2010 and 2012 in Acre state using the PULSE-Brazil platform. Dengue fever data are presented as the number of cases normalized by 10,000 inhabitants. We also used historical minimum temperature data downloaded from the PULSE-Brazil platform. The use of minimum temperature was based on Horta et al. [21], which showed a significant increase in the risk of Dengue fever as a function of minimum temperature increase. We assessed trends of minimum temperature (1950-2012) in Acre state for each one of the months using a linear trend regression. The confidence level of the trends observed for each month was obtained according to the two-tailed student's t distribution (Appendix). To test if trends in minimum temperature covary with trends in Dengue fever cases [21], we selected one municipality of the state of Acre, Acrelândia, and calculated the significance of the trends for the number of Dengue fever cases from 2001 to 2013, based on the same calculations described above.

\subsubsection{Insights from CMIP5 Projections}

Finally, we used the outputs of future climate available in PULSE-Brazil platform to discuss plausible impacts of climate change on respiratory diseases and Dengue fever. We focus on CMIP5 projections of rainfall and minimum temperature. 


\section{Results}

\subsection{Fires and Respiratory Diseases}

Evaluating the data from PULSE-Brazil platform, we show, based on the cumulative monthly age standardized rates (ASR), that the anomalies in hospitalizations (as the departure of the long-term ten year mean 2001-2010) due to respiratory diseases were higher in September 2005 (Figure 1(a)). This peak of over 150 cases per 100,000 inhabitants coincided with increased fire incidence (Figure 1(b)) and aerosol loads in the atmosphere due to biomass burning (Figure 1(c)). During July, August and September of 2005 we observed a 54\% increase in the total number of hospitalizations in comparison to the long-term ten year mean (Figure 1(e)). This pattern followed the higher than average values for fire incidence and AOD (Figure 1(f) and Figure 1(g)) and below average rainfall (Figure 1(h)). Significant positive correlations explaining $23 \%$ and $36 \%$ of the variance in hospitalizations were also identified when testing this variable against fire $(\mathrm{p}=0.04)$ and aerosol optical depth $(\mathrm{p}=$ 0.008), respectively (Figure 1(i) and Figure 1(j)). These significantly positive relationships occurred in parallel with five-month maintenance of below average rainfall from May to September (Figure 1(h)).

The results of the quasi-Poisson regression analysis (Table 2) confirmed the significance of the direct aerosol effect on respiratory diseases hospitalizations. The significance of aerosol effect on hospitalizations was also confirmed using AOD as a single variable in the regression model. The resulting model for all variables was (Equation (1)):

$$
\log _{\text {resp }}=-7.53-(0.0023 \times \text { rain })+(0.0002 \times \text { fire })+(1.0284 \times A O D)
$$

were resp is the incidence of respiratory diseases and rain, fire, $A O D$ are the monthly values of rainfall (mm), active fire incidence (counts) and aerosol optical depth (adimentional), respectively.


Figure 1. (a) Temporal patterns of the number of hospitalizations (direct age standardized rates) due to respiratory diseases in Acre state, (b) active fires, (c) aerosol optical depth (AOD) and (d) rainfall. Red lines correspond to the mean values between 2001 and 2010 and black lines to the 2005 values. Panels ((e)-(h)) present the 2005 anomalies for the same variable in ((a)-(d)), respectively. The anomalies were quantified as the departure from the 2001-2010 mean. Note that positive and negative anomaly values correspond to values higher and lower than the mean value for each month. Panels (i), (j) and (l) depict to the linear relationship between age standardized rates (ASR) of hospitalizations and the number of active fires, aerosol optical depth and rainfall, respectively. Each point data correspond to a municipality of Acre state affected by drought $(\mathrm{n}=$ 18). 
Table 2. Parameter estimates for hospitalisations caused by respiratory diseases (resp) using a quasi-poisson model.

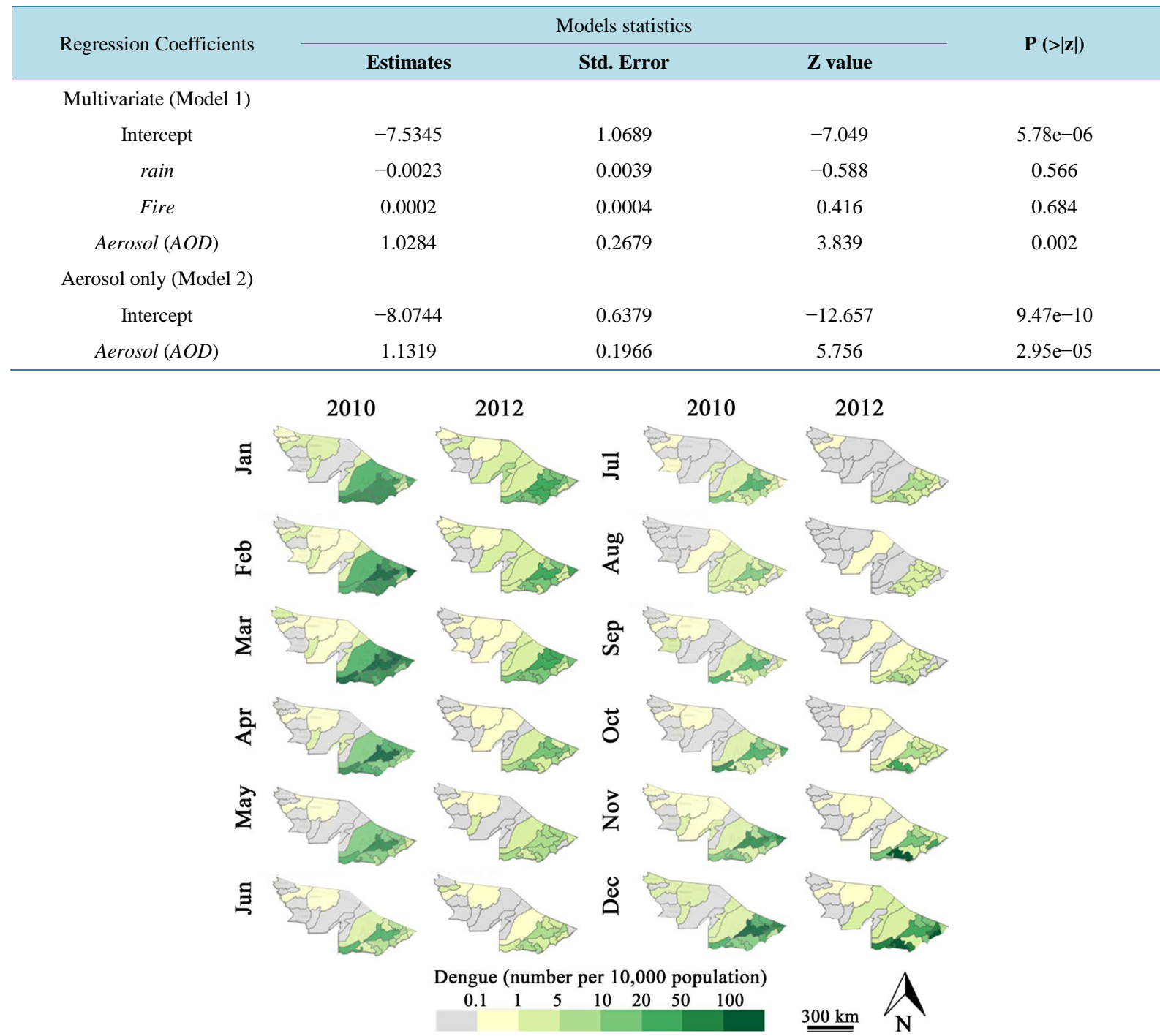

Figure 2. Spatial and temporal patterns of dengue fever occurrence in acre state for the years 2010 and 2012. Polygons represent the municipalities of acre state. Units are in number of cases per 10,000 inhabitants.

\subsection{Temperatures and Dengue Fever Outbreaks}

Southwestern Amazonia, specifically Acre state, has been systematically exposed to Dengue fever outbreaks. Comparing the number of Dengue fever cases between the year of 2010 and 2012, we demonstrated that for both years the number of cases was higher during the wet season, especially in the months of January, February and March (Figure 2). Moreover, it is important to highlight that Acre municipalities located in southeast flank of the state tended to reach over 100 cases of Dengue fever per 10,000 inhabitants during the wet season. It is interesting to note that the number of Dengue fever cases was higher in 2010 than in 2012. While values of cases for February, March, April reached over 100 cases per 10,000 inhabitants in some municipalities in 2010, it never surpassed this threshold for the same months in 2012.

Using PULSE-Brazil graphic outputs we showed that in seven of the 12 months analyzed (58\%), $\mathrm{T}_{\min }$ was higher in 2010 than in 2012 (Figure 3). Most importantly, for all months of the first quarter of the year, when Dengue fever outbreak was in its maximum, $T_{\min }$ in 2010 exceeded those observed in 2012, corroborating previous findings. By extracting the raw $\mathrm{T}_{\min }$ data from PULSE-Brazil platform we also calculated the long-term linear trend from 1950 to 2012 . We found significant trends $(\mathrm{p}<0.05)$ of increase in $\mathrm{T}_{\min }$ from January to May. 
L. E. O. C. Aragão et al.

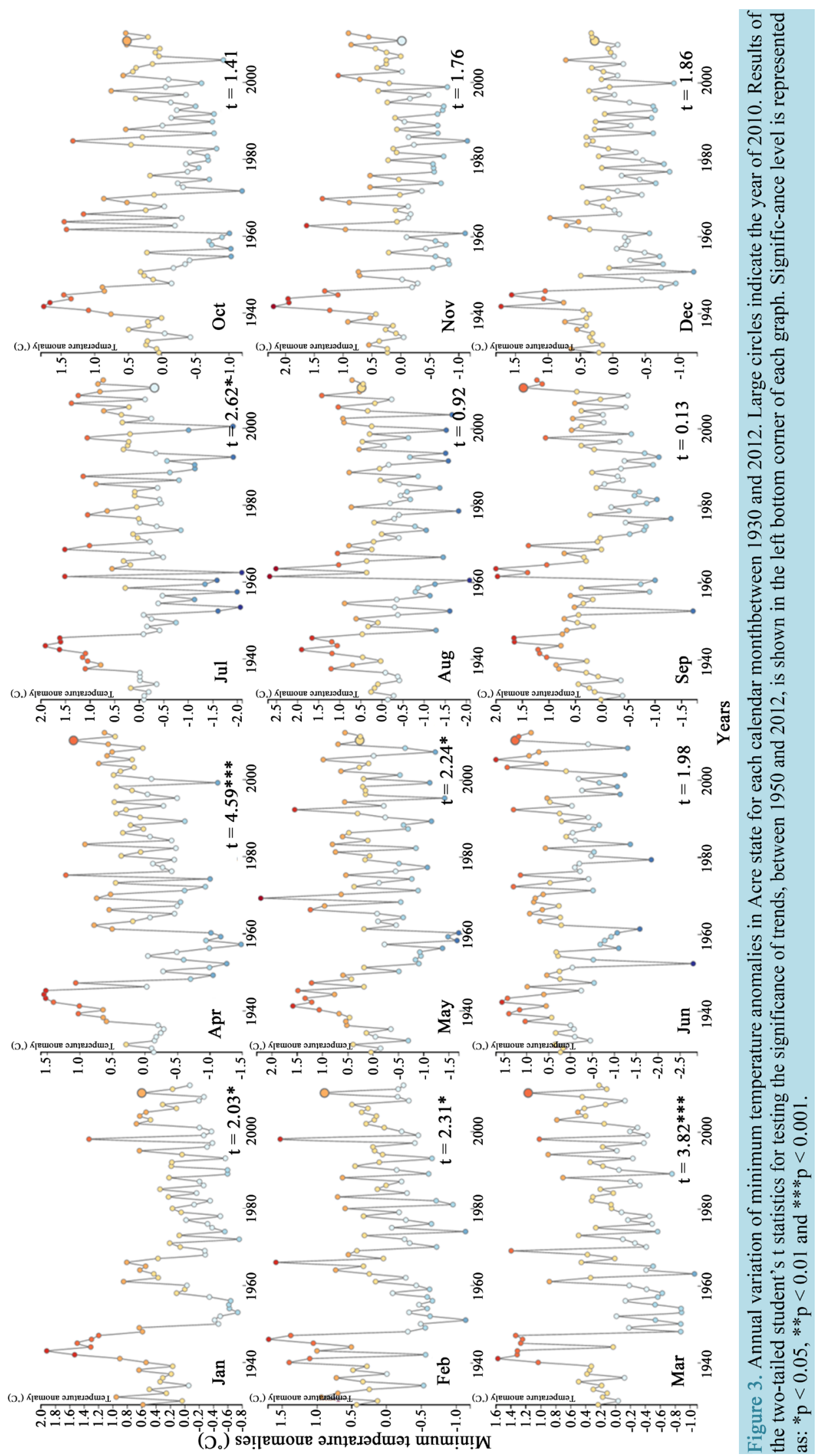


The most significant trends ( $\mathrm{p}<0.001$ ) were found for March $(\mathrm{t}=3.82)$ and April $(\mathrm{t}=4.59)$ (Figure 3).

To test the association between temperature and dengue fever incidence, we extracted from PULSE-Brazil platform data about monthly number of Dengue fever cases from 2000 to 2013 for the municipality of Acrelândia. For each month, we calculated the linear trend along the years analyzed. Plotting the values of the t-test statistic of Dengue fever cases against the t-test statistic of minimum temperature, calculated as described above, we found an apparent consistency between the two variables (Figure 4). This indicates that in months with significantly positive long-term trends in minimum temperature, there is a corresponding positive trend in Dengue fever incidence. This correspondence is visualized in the inset plot of Figure 4 ( $r=0.75, n=12$ months, $p<0.01$ ).

\subsection{Insights from CMIP5 Projections}

The key purpose of PULSE-Brazil platform is to make possible the understanding of the interrelationships between climate, ecosystems and human health variables based on historical data to be able to idealize future trends in the frequency and magnitude of impacts. This is a critical part of the exercise of building resilience and reducing vulnerability of tropical populations to climate change. In this context, we offer within the PULSEBrazil platform the ensemble of CMIP5 models for long-term planning of mitigation and adaptation actions related to the identified impacts.

Knowing that respiratory diseases are significantly associated with increased fire incidence and atmospheric aerosols emissions (Figure 1), as a consequence of droughts; we interrogate CMIP5 daily precipitation anomaly data for August, September and October (Figures 5(a)-(c), respectively) in Acre state to envisage the long-term risk of fire-associate respiratory diseases. The evaluation of the graphic outputs of the platform indicated an increased variability and a slightly negative trend in rainfall anomalies. Moreover, CMIP5 projections of minimum temperature anomalies for January, February and March (Figures 5(c)-(e), respectively) indicated, as expected, a positive trend in $\mathrm{T}_{\min }$, which can lead to an exacerbation of Dengue fever cases in the region.

\section{Discussion}

We showed significant connections between droughts, fire and respiratory diseases for inhabitants under-five years of age in Acre state, the epicentre of the 2005 drought. This drought characterized by dry air conditions and high temperatures induced an anomalous increase in the number of active fire detections [10]. Smith et al. [22] showed that aerosol loads and a broad social stressor, the Human Development Index (HDI), were the primary drivers of respiratory health problems during the 2005 and 2010 droughts in Amazonia. These droughts were linked to anomalous warming of the waters in the tropical North Atlantic Ocean, associated with the Atlantic Multidecadal Oscillation (AMO) cycle [6] [7] as in 2005, or to anomalous warming of the waters in the Equatorial Pacific Ocean ENSO [23] as in 2010. In addition to human health consequences exposed here, the droughts in southwest part of Amazonia in 2005 and 2010, also affected a large fraction of Acre state forests,



Figure 4. Monthly two-tailed student's t values of the annual trend (2000-2013) for each calendar month. The trends were calculated for both Dengue fever cases and minimum temperature $\left(\mathrm{T}_{\min }\right)$. In the inset we show the direct relationship between the trends in Dengue fever and trends in minimum temperature. 


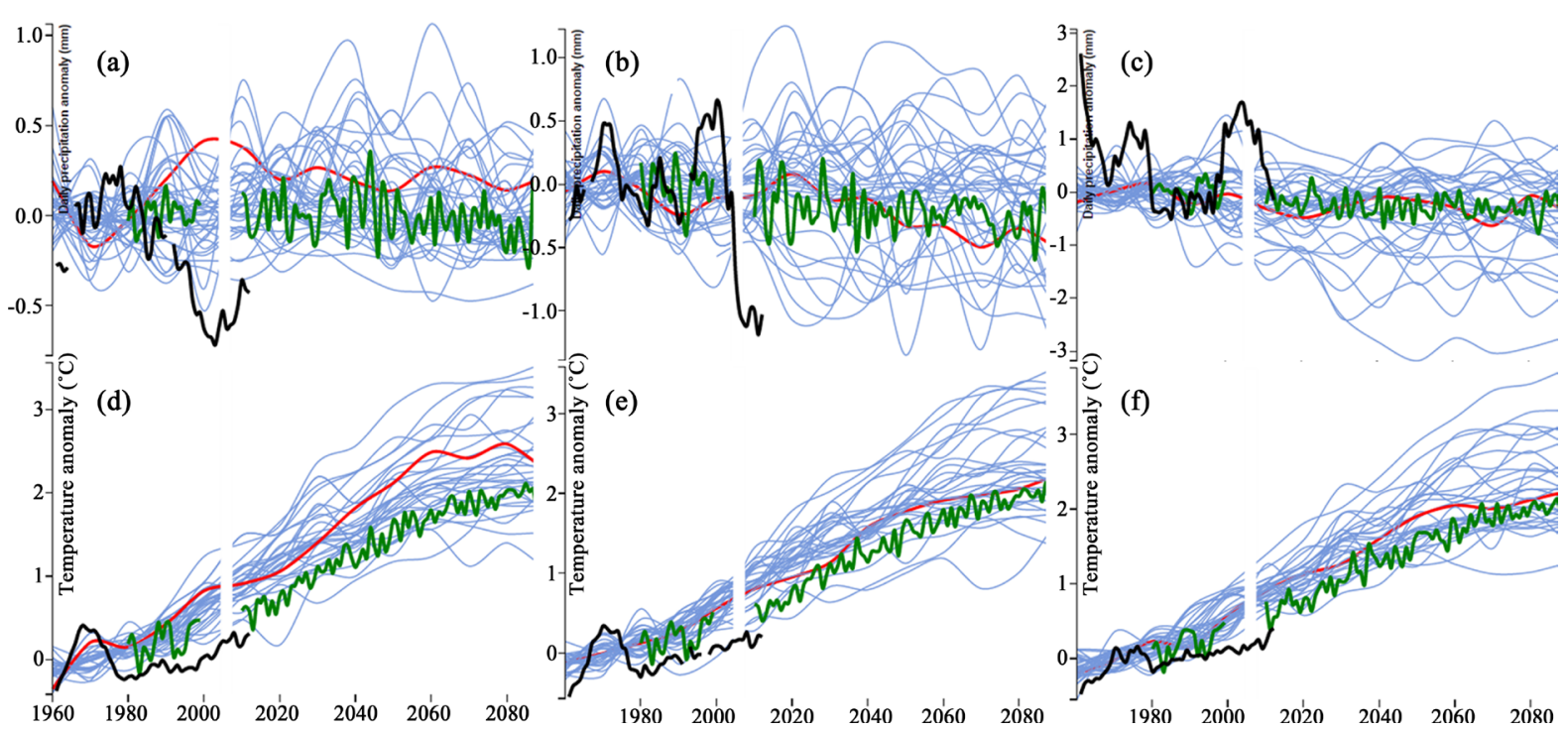

Figure 5. Projections from CMIP5 climate models for acre state, highlighting observations from CRU (black line), CMIP5 annual average (green line), specific model outputs (blue line) and CMIP5 member displayed on the map (red line). Top panels show monthly precipitation anomaly projections for (a) August, (b) September and (c) October. Bottom panels show monthly minimum temperature anomalies projections for (d) January, (e) February and (f) March.

ranging from 280,000 ha to 417,000 ha, with potential impacts on carbon stocks and other ecosystems services [4] [24] [25].

Furthermore, we also depicted a coherent seasonal pattern in Dengue fever cases (Figure 3), showing that the majority of Dengue fever cases occurred in the wet season [26]. These results corroborate with observations that rainfall is the main variable that influences habitat availability for the Dengue fever mosquito Aedes aegypti [27]. Based on Horta et al. [21], which showed that a rise in minimal temperature $\left(\mathrm{T}_{\min }\right)$ causes an increase of $37 \%$ in the risk of Dengue fever, we also tested whether $\mathrm{T}_{\min }$ was higher in 2010 (drought year) in relation to 2012, and found a significant covariation between trends in $\mathrm{T}_{\min }$ and Degue fever occurrence. As temperature controls the life cycle and behavior of vector populations, as well as viral replication rates within the mosquito [28], positive trends in temperature is likely to lead to an increase of Dengue fever incidence.

The trends and variability of rainfall anomalies found when analyzing CMIP5 dataset, points toward a drier climate with higher probability of extreme events in this region. Therefore, if no actions are implemented in order to curb fire, we expect that a larger fraction of the population and ecosystems will be at increased exposure to respiratory diseases and loss of ecosystems functions, respectively. The combination of rainfall variability and temperature indicates that if wet season rainfall is able to provide enough habitat area for the development of mosquito larvae, the increased trend in temperature is likely to favor mosquito and Dengue fever virus development escalating the proportion of vulnerable population.

It is thus essential to Acre and other Amazonian states to intensify Dengue fever control, as our results point to a scenario of increased exposure of human populations in the future. Vector control is largely done by education of citizens aiming for larvae habitat elimination and reduction [29] and space spraying [30]. However, mitigation of the epidemic process has been a function of herd immunity and depletion of susceptible individuals rather than efficient vector control [31]. So, control requires integrated policies between various sectors of society to improve the effectiveness of vector control and to develop an efficient vaccine to immunize the population against Dengue fever serotypes. The PULSE-Brazil platform powered with health data from the Brazilian government has the potential to be a key partner of the active disease surveillance that has been proposed by the World Health Organization Global Strategy for Prevention and Control of Dengue Fever and Dengue Hemorrhagic Fever [32]. It is interesting to note that Horstick et al. [30] highlighted the fact that none of the countries visited in their study, which includes Brazil, had an established Dengue fever monitoring and evaluation program.

It is well established that changes in atmospheric circulation induced by planetary warming [33] [34], can lead to a rainfall reduction over Amazonia that would potentially exacerbate the synergism between climate, defore- 
station and fires [35] [36]. This scenario is likely to turn the world's largest tropical forest into a more fire-prone system [37], magnifying fire impacts upon carbon stocks, water cycle and especially human health in the Amazon region as demonstrated in this study [10] [22] [38]-[42]. Generally, the exacerbation of respiratory diseases incidence is influenced by biological, social, and environmental factors. Rainfall and relative humidity seasonality are critical elements on the incidence of respiratory diseases, which are a considerable health issue in Brazil. Respiratory diseases are recognized by the World Health Organization (WHO) as a health threat from climate and environmental change [22]. Between 2001 and 2010 more than two million hospitalizations related to respiratory diseases were recorded in Amazonia [43]. These hospitalizations normally peak at the end of the wet season, which could be due to the development of mould and fungi [44] [45]. During droughts however, the spatial and temporal distribution of respiratory diseases shift to correspond with the peak months and locations of extreme drought. This is a consequence of the increased number of fires. It has been observed that during droughts in Amazonian fire activity increases by over 30\% [22] [40] which lead to higher aerosol loads from biomass burning in the region [25]. Models also project that climate change is likely to affect the Dengue fever viruses and vector populations since rainfall influences habitat availability for the Dengue fever mosquito Aedes aegypti [27] and temperature influences vector development rates, mortality, and behavior and also controls viral replication within the mosquito [28]. Over 2.5 billion people are now at risk from Dengue fever and estimates there may be between 50 to 100 million infections worldwide every year [46].

The concept of providing a new platform and paradigm for integrating global environmental change science, designed and conducted by a partnership between scientists and society, to produce the essential information for societal transformations towards sustainability must be in line with international demands and initiatives proposed [47]-[49]. The Future Earth program that is supported by the "Science and Technology Alliance for Global Sustainability" [47] has been pivotal in building this new paradigm of scientific knowledge co-production. The Sendai Framework [13] is also a keystone on setting the boundaries for managing climate risk. Four priorities are clearly identified in this framework: 1) Understanding disaster risk; 2) strengthening disaster risk governance to manage disaster risk; 3) investing in disaster risk reduction for resilience; and 4) enhancing disaster preparedness for effective response and to "Build Back Better" in recovery, rehabilitation and reconstruction [13]. With the understanding of science and policy requirements we propose a conceptual overarching framework for delivering the information from scientists to Brazilian policymakers in order to make effective decisions for increasing resilience. Based on the development of the PULSE-Brazil platform we suggest six steps to align scientific information with policy needs (Figure 6). The understanding of past and future climate patterns is mostly connected to academic research (Figure 6(a)). However, the realization of the consequences is also perceived by the society (Figure 6(b)), which is a key partner to elaborate possible solutions. Therefore, establishing the patterns and possible consequences of environmental impacts on human health and ecosystems is the primordial step to identify stakeholder's needs and its role in the co-design and co-production process (Figure 6(c)) of an analytical and diagnosing framework [47]. In the specific case of this study, the result of this synergism



Figure 6. Architecture of a conceptual model to promote coherent knowledge exchange between science and policy for increasing institutional resilience and reducing vulnerability of cities, states and countries to climate and environmental change impacts. 
was the development of the PULSE-Brazil, which is a platform aiming to build institutional resilience (Figure 6(d)). Building capacity within the institutions to analyze the results provided by the platform is required for allowing decision makers to plan ahead (Figure 6(e)). It is also essential to quantify and interpret impacts (Figure 6(f)) that is aimed to ultimately decrease vulnerability and increase the accuracy of the platform.

\section{Conclusions}

This study demonstrated that translating complex technical information on climate variability and change and its interactions with ecosystems and human populations from scientists to the general public, especially policymakers can be effectively achieved through the use of an integrative platform with readily available environmental datasets and visualization capabilities.

Differently from more complete software-like, adaptation support tools, that allows modeling of climate change impacts, vulnerability and risks, such as the CLIMSAVE impact assessment framework [50] from European Commission's Climate Adaptation Platform (Climate-ADAPT)

(http://climate-adapt.eea.europa.eu/adaptation-support-tool), PULSE-Brazil is a platform that synthesize multisource information on climate, environment and human health in a comprehensive arrangement and allows users to view maps, graphical information and download data (Appendix). Analysis of impacts, vulnerability and risks cannot be achieved within the platform. The PULSE-Brazil resembles other initiatives such as the National Oceanic and Atmospheric Administration (NOAA) Climate.gov platform

(https://www.climate.gov/decision-support/department/decision-support-tools), the Adaptation of Asia-Pacific Forests to Climate Chenge_ClimateAP_MAP (http://climateap.net/) from the University of British Columbia or the Climate Wizard from the Nature Conservancy (http://www.climatewizard.org/).

Because PULSE-Brazil, was specifically design for tackling Brazilian environmental problems, this tool adds value and reinforces the arsenal of tools to support the interchange of information from science to policy. PULSE-Brazil can be classified as a visualization tool according to the Ecosystem-Based Management Tools Network

(https://www.ebmtoolsdatabase.org/resource/climate-change-vulnerability-assessment-and-adaptation-tools), that in its matrix of Climate Change Vulnerability Assessment and Adaptation Tools separate these tools in six categories: 1) process, 2) portals, 3) analytical, 4) visualization, 5) socio-economic and 6) natural resources tools. PULSE-Brazil can also be put into perspective by comparison with the United Nations Framework Convention on Climate Change (UNFCCC) compendium on methods and tools to evaluate climate change impacts, vulnerability and adaptation [18] as well as the work from McIntosh et al. [17] that depict environment decision support systems.

The continuous development of PULSE-Brazil together with governmental collaborators is a viable approach for the elaboration, implementation and long-term assessment of any adaptation and mitigation policies related to the socio-environmental disasters induced by climate change. This approach allows the group of scientists and policymakers to invest efforts on specific problems definition and solution during policy implementation phases [51]. Because the design and development of this web platform has been done in a participatory approach with decision makers and scientists from partner institutions from Brazil and UK, PULSE-Brazil team can guaranty that science remains focused on the needs of the policy process [52]. So, we argue that, at least in this first stage of PULSE development, we have successfully overcame challenges related to engaging end users throughout the design and development process of the platform [17].

The result of this work was a flexible web application focused on user's demands, which efficiently visualizes many different modeling and observed datasets, helping the construction of an understanding of historical impacts of climate extremes on human health and ecosystems as well as possible future risks under a global climate change scenario. This study clearly shows that ecosystems are under increased fire risk in the future that will in turn affect the health of human populations. Moreover, humans are also exposed to critical Dengue fever outbreaks with the projected increase in minimum temperatures. Therefore, mitigating these potential impacts is the first step for adapting to a changing climate in the Amazon region.

We expect that PULSE-Brazil serves not only as a technical tool for subsidizing climate impact mitigation strategies and long-term adaptation plans, but also take advantage of its graphical capabilities to be an instructive vehicle that facilitates information flow and activities coordination among governmental institutions and civil society. As suggested by Reis et al. [53], public health has still been pursued disconnecting human lives 
and ecosystems. Therefore, PULSE-Brazil is intent to contribute to better governance in integrating environmental, science and technology, and health sectors aiming to support the planning of sustainable pathways for the nation.

\section{Acknowledgements}

The PULSE-Brazil project was sponsored by NERC funding to University of Exeter and (project NE/J016276/1), and FAPESP funding to INPE and CEMADEN (project 2011/51843-2). LEOCA and JAM acknowledges the support of CNPq (Productivity fellowship) and FAPESP-Belmont Forum funding ( $\mathrm{n}^{\circ}$ 2012/51876-0). LEOCA also thank CNPQ for the grant 458022/2013-6. LOA thank NERC funding NE/F005482/1, CNPq grant 400640/ 2012-0 and NASA-IDS grant NNX14AD31G.

\section{References}

[1] Espinoza, J.C., Lengaigne, M., Ronchail, J. and Janicot, S. (2012) Large-Scale Circulation Patterns and Related Rainfall in the Amazon Basin: A Neuronal Networks Approach. Climate Dynamics, 38, 121-140. http://dx.doi.org/10.1007/s00382-011-1010-8

[2] Espinoza, J.C., Ronchail, J., Guyot, J.L., Junquas, C., Drapeau, G., Martinez, J.M., Santini, W., Vauchel, P., Lavado, W., Ordoñez, J. and Espinoza, R. (2012) From Drought to Flooding: Understanding the Abrupt 2010-2011 Hydrological Annual Cycle in the Amazonas River and Tributaries. Environmental Research Letters, 7, 024008. http://dx.doi.org/10.1088/1748-9326/7/2/024008

[3] Espinoza, J.C., Marengo, J.A., Ronchail, J., Molina, J., Noriega, L. and Guyot, J.L. (2014) The Extreme 2014 Flood in South-Western Amazon Basin: The Role of Tropical-Subtropical South Atlantic SST Gradient. Environmental Research Letters. http://dx.doi.org/10.1088/1748-9326/9/12/124007

[4] Lewis, S.L., Brando, P.M., Phillips, O.L., van der Heijden, G.M.F. and Nepstad, D. (2011) The 2010 Amazon Drought. Science, 331, 554. http://dx.doi.org/10.1126/science.1200807

[5] Cox, P.M., Harris, P.P., Huntingford, C., Betts, R.A., Collins, M., Jones, C.D., Jupp, T.E., Marengo, J.A. and Nobre, C.A. (2008) Increasing Risk of Amazonian Drought Due to Decreasing Aerosol Pollution. Nature, 453, 212-215. http://dx.doi.org/10.1038/nature06960

[6] Marengo, J.A., Nobre, C.A., Tomasella, J., Oyama, M.D., Oliveira, G.S., de Oliveira, R., Camargo, H., Alves, L.M. and Brown, I.F. (2008) The Drought of Amazonia in 2005. Journal of Climate, 21, 495-516. http://dx.doi.org/10.1175/2007JCLI1600.1

[7] Marengo, J.A., Nobre, C.A., Tomasella, J., Cardoso, M.F. and Oyama, M.D. (2008) Hydro-Climatic and Ecological Behaviour of the Drought of Amazonia in 2005. Philosophical Transactions of the Royal Society of London. Series B, Biological Sciences, 363, 1773-1778. http://dx.doi.org/10.1098/rstb.2007.0015

[8] Marengo, J.A., Alves, L.M., Soares, W.R., Rodriguez, D.A., Camargo, H., Paredes, M. and Diaz Pablo, A. (2013) Two Contrasting Seasonal Extremes in Tropical South America in 2012: Flood in Amazonia and Drought in Northeast Brazil. Journal of Climate, 26, 9137-9154. http://dx.doi.org/10.1175/JCLI-D-12-00642.1

[9] Marengo, J.A. and Espinoza, J.C. (2015) Extreme Seasonal Droughts and Floods in Amazonia: Causes, Trends and Impacts. International Journal of Climatology.

[10] Aragão, L.E.O., Malhi, Y., Roman-Cuesta, R.M., Saatchi, S., Anderson, L.O. and Shimabukuro, Y.E. (2007) Spatial Patterns and Fire Response of Recent Amazonian Droughts. Geophysical Research Letters, 34. http://dx.doi.org/10.1029/2006GL028946

[11] Tomasella, J., Borma, L.S., Marengo, J.A., Rodriguez, D.A., Cuartas, L.A., Nobre, C.A. and Prado, M.C. (2011) The Droughts of 1996-1997 and 2004-2005 in Amazonia: Hydrological Response in the River Main-Stem. Hydrological Processes, 25, 1228-1242. http://dx.doi.org/10.1002/hyp.7889

[12] UNISDR (United Nations International Strategy for Disaster Reduction) (2007) Hyogo Framework for Action 20052015: Building the Resilience of Nations and Communities to Disasters. Extract from the Final Report of the World Conference on Disaster Reduction (A/CONF.206/6). Geneva.

[13] UNISDR (United Nations International Strategy for Disaster Reduction) (2015) Sendai Framework for Disaster Risk Reduction 2015-2030. UNISDR, Geneva.

[14] Marengo, J.A., Aragão, L.E.O.C., Cox, P.M., Betts, R., Costa, D., Kaye, N., Smith, L.T., Alves, L.M. and Reis, V. (2016) Impacts of Climate Extremes in Brazil: The Development of a Web Platform for Understanding Long-Term Sustainability of Ecosystems and Human Health in Amazonia (PULSE-Brazil). Bulletin of the American Meteorological Society. http://dx.doi.org/10.1175/BAMS-D-14-00177.1 
[15] Costanza, R. (2003) A Vision of the Future of Science: Reintegrating the Study of Humans and the Rest of Nature. Futures, 35, 651-671. http://dx.doi.org/10.1016/S0016-3287(02)00105-2

[16] McIntosh, B.S., Seaton, R.A.F. and Jeffrey, P. (2007) Tools to Think with? Towards Understanding the Use of Computer-Based Support Tools in Policy Relevant Research. Environmental Modelling \& Software, 22, 640-648. http://dx.doi.org/10.1016/j.envsoft.2005.12.015

[17] McIntosh, B.S., Ascough, J.C., Twery, M., Chew, J., Elmahdi, A., Haase, D., Chen, S., et al. (2011) Environmental decision Support Systems (EDSS) Development-Challenges and Best Practices. Environmental Modelling \& Software, 26, 1389-1402. http://dx.doi.org/10.1016/j.envsoft.2011.09.009

[18] UNFCCC Secretariat (2008) Compendium on Methods and Tools to Evaluate Impacts of, and Vulnerability and Adaptation to, Climate Change. With the Services of Pinto, E., Kay, R.C. and Travers, A., CZM pty. Ltd., Stratus Consulting Inc., UNFCCC Secretariat

[19] Lovett, A. and Flowerdew, R. (1989) Analysis of Count Data Using Poisson Regression. Professional Geographer, 41, 190-198. http://dx.doi.org/10.1111/j.0033-0124.1989.00190.x

[20] Hilbe, J. (2007) Negative Binomial Regression. Cambridge University Press, New York, 264. http://dx.doi.org/10.1017/CBO9780511811852

[21] Horta, M.A., Fonseca, P.A., Costa, D., Barcellos, C. and Hacon, S. (2014) Temporal Relationship between Climatic Factors and the Occurrence of Dengue Fever in an Amazonian Urban Center, Brazil. International Journal of Epidemiology \& Infection, 2, 80-87. http://dx.doi.org/10.12966/ijei.11.04.2014

[22] Smith, L.T., Aragão, L.E., Sabel, C.E. and Nakaya, T. (2014) Drought Impacts on Children’s Respiratory Health in the Brazilian Amazon. Scientific Reports, 4, Article Number: 3726. http://dx.doi.org/10.1038/srep03726

[23] Marengo, J.A., Tomasella, J., Alves, L.M., Soares, W. and Rodriguez, D.A. (2011) The Drought of 2010 in the Context of Historical Droughts in the Amazon Region. Geophysical Research Letters, 38, Article ID: L12703. http://dx.doi.org/10.1029/2011GL047436

[24] Shimabukuro, Y.E., Duarte, V., Arai, E., Freitas, R.M., Lima, A., Valeriano, D., Brown, I.F. and Maldonado, M. (2009) Fraction Images Derived from Terra Modis Data for Mapping Burnt Areas in Brazilian Amazonia. International Journal of Remote Sensing, 30, 1537-1546. http://dx.doi.org/10.1080/01431160802509058

[25] Gatti, L.V., et al. (2014) Drought Sensitivity of Amazonian Carbon Balance Revealed by Atmospheric Measurements. Nature, 506, 76-80. http://dx.doi.org/10.1038/nature12957

[26] Pham, H.V., Doan, H.T.M., Phan, Y.Y.Y. and Minh, N.N.T. (2011) Ecological Factors Associated with Dengue Fever in a Central Highlands Province, Vietnam. BMC Infectious Diseases, 11, 172. http://dx.doi.org/10.1186/1471-2334-11-172

[27] Morin, C.W., Comrie, A.C. and Ernst, K. (2013) Climate and Dengue Transmission: Evidence and Implications. Environmental Health Perspectives, 121, 1264-1272. http://dx.doi.org/10.1289/ehp.1306556

[28] Hales, S., De Wet, N., Maindonald, J. and Woodward, A. (2002) Potential Effect of Population and Climate Changes on Global Distribution of Dengue Fever: An Empirical Model. The Lancet, 360, 830-834. http://dx.doi.org/10.1016/S0140-6736(02)09964-6

[29] Degallier, N.I.C.O.L.A.S., Vilarinhos, P.D.T.R., de Carvalho, M.L., Knox, M.B. and Caetano Jr., J. (2000) People’s Knowledge and Practice about Dengue Fever, Its Vectors, and Control Means in Brasilia (DF), Brazil: Its Relevance with Entomological Factors. Journal of the American Mosquito Control Association, 16, 114-123.

[30] Horstick, O., Runge-Ranzinger, S., Nathan, M.B. and Kroeger, A. (2010) Dengue Vector-Control Services: How Do They Work? A Systematic Literature Review and Country Case Studies. Transactions of the Royal Society of Tropical Medicine and Hygiene, 104, 379-386. http://dx.doi.org/10.1016/j.trstmh.2009.07.027

[31] Medronho, R.A. (2006) Dengue e o ambienteurbano. Revista Brasileira de Epidemiologia, 9, 159-161. http://dx.doi.org/10.1590/S1415-790X2006000200002

[32] WHO (1995) Global Strategy for Prevention and Control of Dengue Fever and Dengue Haemorrhagic Fever: Report of the Consultation on Key Issues in Dengue Vector Control towards the Operationalization of a Global Strategy. CTD/ FIL(DEN)/IC/96, World Health Organization, Geneva.

[33] IPCC (2013) Summary for Policymakers. In: Field, C., Barros, V.R., DOkken, D.J., Mach, K.J., Mastrandrea, M.D., Bilir, T.E., Chatterjhee, M., Ebi, K.L., Estrada, Y.O., Genova, R.C., Girma, B., Kissel, E.S., Levy, A.N., MacCracken, S., Mastrandrea, P.R. and White, L.L., Eds., Climate Change 2013: Impacts, Vulnerabiliuty and Adaptation, Part A: Global and Sectoiral Aspects, Contribution of Working Group 2 to the Fifth Assessment Report of the Intergovernmental Panel on Climate Change, Cambridge University Press, Cambridge, 1-32

[34] IPCC (2014) Climate Change 2014: Impacts, Adaptation, and Vulnerability. Part A: Global and Sectoral Aspects. Contribution of Working Group II to the Fifth Assessment Report of the Intergovernmental Panel on Climate Change. Field, C., Barros, V.R., DOkken, D.J., Mach, K.J., Mastrandrea, M.D., Bilir, T.E., Chatterjhee, M., Ebi, K.L., Estrada, Y.O., 
Genova, R.C., Girma, B., Kissel, E.S., Levy, A.N., MacCracken, S., Mastrandrea, P.R. and White, L.L., Eds., Cambridge University Press, Cambridge, 1132.

[35] Cochrane, M.A. and Laurance, W.F. (2002) Fire as a Large-Scale Edge Effect in Amazonian Forests. Journal of Tropical Ecology, 18, 311-325. http://dx.doi.org/10.1017/S0266467402002237

[36] Hutyra, L.R., Munger, J.W., Nobre, C.A., Saleska, S.R., Vieira, S.U. and Wofsy, S.C. (2005) Climatic Variability and Vegetation Vulnerability in Amazonia. Geophysical Research Letters, 32, Article ID: L24712. http://dx.doi.org/10.1029/2005gl024981

[37] Malhi, Y., Roberts, J.T., Betts, R.A., Killeen, T.J., Li, W. and Nobre, C.A. (2008) Climate Change, Deforestation, and the Fate of the Amazon. Science, 319, 169-172. http://dx.doi.org/10.1126/science.1146961

[38] Alencar, A., Nepstad, D. and Vera Diaz, M.C. (2006) Forest Understory Fire in the Brazilian Amazon in Enso and Non-Enso Years: Area Burned and Committed Carbon Emissions. Earth Interactions, 10, 1-17. http://dx.doi.org/10.1175/EI150.1

[39] Anderson, L.O., Malhi, Y., Aragão, L.E.O.C., Ladle, R., Arai, E., Barbier, N. and Phillips, O. (2010) Remote Sensing Detection of Droughts in Amazonian Forest Canopies. New Phytologist, 187, 733-750. http://dx.doi.org/10.1111/j.1469-8137.2010.03355.x

[40] Aragão, L.E.O.C., Malhi, Y., Barbier, N., Lima, A., Shimabukuro, Y., Anderson, L. and Saatchi, S. (2008) Interactions between Rainfall, Deforestation and Fires during Recent Years in the Brazilian Amazonia. Philosophical Transactions of the Royal Society B Biological Sciences, 363, 1779-1785. http://dx.doi.org/10.1098/rstb.2007.0026

[41] Cochrane, M.A. and Laurance, W.F. (2008) Synergisms among Fire, Land Use, and Climate Change in the Amazon. Ambio: A Journal of the Human Environment, 37, 522-527. http://dx.doi.org/10.1579/0044-7447-37.7.522

[42] Matricardi, E., Skole, D.L., Pedlowski, M.A. and Chomentowski, W. (2013) Assessment of Forest Disturbances by Selective Logging and Forest Fires in the Brazilian Amazon Using Landsat Data. International Journal of Remote Sensing, 34, 1057-1086. http://dx.doi.org/10.1080/01431161.2012.717182

[43] Datasus (2011) Transferência de arquivos. Ministério da saude/DATASUS—Departamento de Informática do SUS. http://www2.datasus.gov.br/DATASUS/index.php?area=0901\&item=1\&acao=25

[44] Croce, M., Vasconcelos, D.M., Manso, E.R. and Duarte, A.J. (1998) Poluição ambiental e alergia respiratória. Medicina, 31, 144-153. http://dx.doi.org/10.11606/issn.2176-7262.v31i1p144-153

[45] Pauliquevis, T., Artaxo, P., Oliveira, P.H. and Paixão, M. (2007) O papel das partículas de aerossol no funcionamento do ecossistemaamazônico. Ciência e Cultura, 59, 48-50.

[46] Pessanha, J.E.M. (2012) Risk Assessment and Risk Maps Using a Simple Dengue Fever Model. Dengue Bulletin, 36, 73-86.

[47] Mauser, W., Klepper, G., Rice, M., Schmalzbauer, B.S., Hackmann, H., Leemans, R. and Moore, H. (2013) Transdisciplinary Global Change Research: The Co-Creation of Knowledge for Sustainability. Current Opinion in Environmental Sustainability, 5, 420-431. http://dx.doi.org/10.1016/j.cosust.2013.07.001

[48] Meadow, A.M., Ferguson, D.B., Guido, Z., Horangic, A., Owen, G. and Wall, T. (2015) Moving toward the Deliberate Co-Production of Climate Science Knowledge. Weather, Climate, and Society, 7, 179-191. http://dx.doi.org/10.1175/WCAS-D-14-00050.1

[49] Weaver, C.P., Mooney, S., Allen, D., Beller-Simms, N., Fish, T., Grambsch, A.E. and Winthrop, R. (2014) From Global Change Science to Action with Social Sciences. Nature Climate Change, 4, 656-659. http://dx.doi.org/10.1038/nclimate2319

[50] Harrison, P.A., Holman, I.P., Cojocaru, G., Kok, K., Kontogianni, A., Metzger, M.J. and Gramberger, M. (2013) Combining Qualitative and Quantitative Understanding for Exploring Cross-Sectoral Climate Change Impacts, Adaptation and Vulnerability in Europe. Regional Environmental Change, 13, 761-780. http://dx.doi.org/10.1007/s10113-012-0361-y

[51] Voinov, A., Seppelt, R., Reis, S., Nabel, J.E.M.S. and Shokravi, S. (2014) Values in Socio-Environmental Modelling: Persuasion for Action or Excuse for Inaction. Environmental Modelling \& Software, 53, 207-212, http://dx.doi.org/10.1016/j.envsoft.2013.12.005

[52] Reis, S., Grennfelt, P., Klimont, Z., Amann, M., ApSimon, H., Hettelingh, J.-P., Holland, M., LeGall, A.-C., Maas, R., Posch, M., Spranger, T., Sutton, M.A. and Williams, M. (2012) From Acid Rain to Climate Change. Science, 338, 1153-1154. http://dx.doi.org/10.1126/science.1226514

[53] Reis, S., Morris, G., Fleming, L.E., Beck, S., Taylor, T., White, M., Depledge, M.H., Steinle, S., Sabel, C.E., Cowie, H. and Hurley, F. (2015) Integrating Health and Environmental Impact Analysis. Public Health, 129, 1383-1389. http://dx.doi.org/10.1016/j.puhe.2013.07.006

[54] Espinoza, J.C., Lengaigne, M., Ronchail, J. and Janicot, S. (2012) Large-Scale Circulation Patterns and Related Rain- 
fall in the Amazon Basin: A Neuronal Networks Approach. Climate Dynamics, 38, 121-140. http://dx.doi.org/10.1007/s00382-011-1010-8

[55] Taylor, K.E., Stouffer, R.J. and Meehl, G.A. (2012) An Overview of CMIP5 and the Experiment Design. Bulletin of the American Meteorological Society, 93, 485-498. http://dx.doi.org/10.1175/BAMS-D-11-00094.1

[56] Giglio, L. (2010) MODIS Collection 5 Active Fire Product User’s Guide Version 2.4. Science Systems and Applications Inc., University of Maryland, Department of Geography.

[57] Meade, M.S. and Emch, M. (2010) Medical Geography. 3rd Edition, the Guilford Press, New York.

[58] Julious, S., Nicholl, J. and George, S. (2001) Why Do We Continue to Use Standardized Mortality Ratios for Small Area Comparisons? Journal of Public Health, 23, 40-46. http://dx.doi.org/10.1093/pubmed/23.1.40 


\section{Appendix}

\section{A1. Capabilities of the PULSE-Brazil Platform}

The PULSE-Brazil platform, co-produced by three working groups composed of scientists, technical and policy advisers from Acre, is a web application developed using open source technologies to create a visualization and analysis tool [14]. This tool enable users to perform interactive querying, visualize maps, and graphs with spatial and temporal information about climate (observed and projected), environment and human health. The platform uses gridded historical climate observations from the Climatic Research Unit (CRU, reference), product CRU TS 3.21, at a 1ox1o spatial resolution with data (http://catalogue.ceda.ac.uk/uuid/ac4ecbd554d0dd52a9b575d9666dc42d). In this version of PULSE-Brazil, we introduced data up to the year of 2012. Figure S1 shows a map of South America and a graph of both the annual trend and also the seasonal cycle of temperature. Clicking on a state allows the display of maps for temperature and precipitation.

The PULSE-BRAZIL platform, moreover, is equipped with an ensemble of 20 climate models from the CMIP5 archive (as used in the IPCC 5th Assessment), for the mid-range RCP4.5 scenario [54]. The platform is set to display decadal average maps (from 2010 to 2090) and graphs quantifying the climate (e.g. temperature, rainfall and runoff) departures (anomalies) from the long-term mean between 1961 and 1990. Interactive graphs are available showing 10 year means that combine observational and projected data (Figure S2).

A regional hospitalization dataset for climate and environmental sensitive diseases: Malaria, Dengue fever, Diarrhoea, Leptospirosis and respiratory diseases, is also publicly available through the Brazilian law number 12.527/2011 that regulates the constitutional rights of public information access. In addition, hospitalization and death rates data related to these diseases for the whole country are been prepared for incorporation into the platform. This database is made publicly available by the Brazilian Ministry of Health through the platform DATASUS (Data System of the Unified Health System in Brazil).

PULSE-Brazil platform also displays river level datasets encompassing a period of over 40 years, made available by Acre government for the Brazilian state of Acre. Furthermore, two other variables that are tested in

(a)

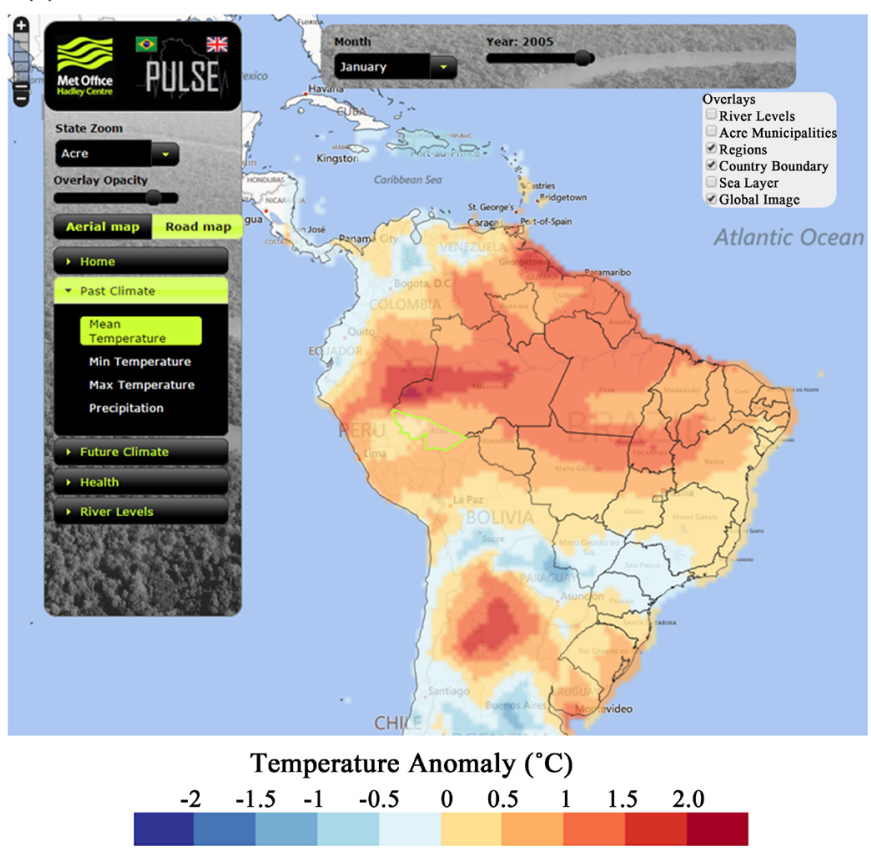

(b)

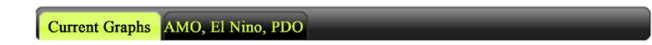

Mean Temperature Anomaly over Acre

The map shows the gridded values for Mean temperature anomaly over Brazil The top graph shows the absolute average value across the state for January 2005
and the year before and after. The bottom graph shows state average anomaly and the year before and after. The bottom graph shows state average ano
values as an annual series for January The data is the gridded CRU TS 3.21 dataset produced by the Climatic Research Unit (CRU) at the University of
goes up to the end of December 2012

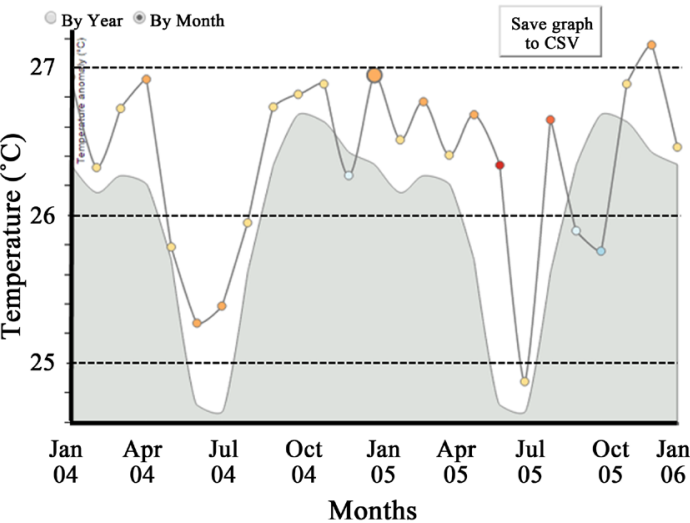

Figure S1. Example of climate observations visualized with the PULSE-Brazil Platform. (a) observed temperature anomalies $\left({ }^{\circ} \mathrm{C}\right)$ over South America for January 2005; (b) seasonal cycles of temperature for the State of Acre for the years either side of the selected month (January 2005), with the grey areas denoting the long-term climatology. The PULSE-Brazil Platform provides o brief description of the data presented for each graph produced. Moreover, the user can download the data in display. 
(a)

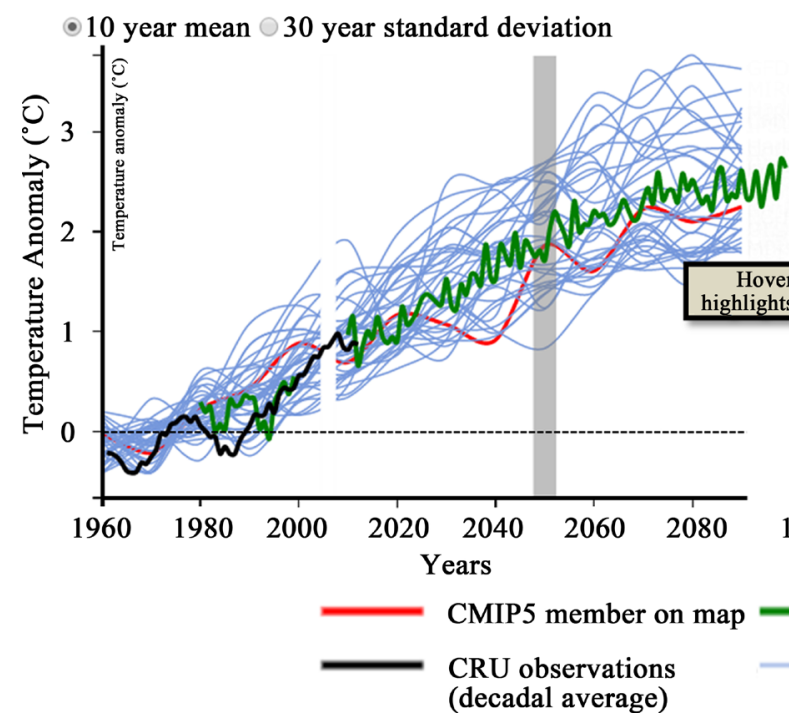

(b)

Figure S2. Example climate projections for 2050 visualized with the PULSE-Brazil Platform. (a) Temperature projections from CMIP5 climate models and observations from CRU (black line); (b) comparison between CMIP5 annual average (green line) and specific model output (blue line), revealed when the user hovers over the graph.

the case study described below will be incorporated into the system. MODIS collection 5 Global Monthly Fire Location Product (MCD14ML) [55] provides the geographic coordinates of each individual $1 \mathrm{~km}^{2}$ active fire pixel detected by the TERRA and AQUA satellites across the globe, for every month since July 2002. Aerosol Optical Depth/Thickness data (AOD/AOT MOD08_M3 collection 051) inform the atmospheric optical depth over land and ocean for particles at 0.55 microns.

\section{A2. Calculating Standardized Rates for Respiratory Diseases and Linear Trends Using Two-Tailed Student's T Distribution}

The general equation for calculating the standardized rates for respiratory diseases can be seen below:

$$
\frac{\sum M_{x} \times P_{x}^{s}}{\sum P_{x}^{s}}
$$

where $M$ is the morbidity rate, $P$ is the population at risk, $x$ is the age group, and $s$ is the standard population [56]. The standard population used was the WHO standard. Standardization usually involves adjustment to a common standard (e.g. incidence rate per 100,000 population) [57] [58].

For calculating the confidence level of the trends using two-tailed student's t distribution we first calculated the t-score for each month by dividing the slope $b$ of the regression line by its respective standard error $S E$ according to Equation (2):

$$
t=b / S E
$$

The slope of the trend regression is defined as (Equation (3)):

$$
b=\frac{\sum(x-\bar{x})(y-\bar{y})}{\sum(x-\bar{x})^{2}}
$$

where $x$ corresponds to the specific year (independent variable), $\bar{x}$ is the average of all years, $y$ is the temperature (dependent variables) for the specific year $x$ and $\bar{y}$ is the temperature average between all years. The standard error of the regression slope is defined as (Equation (4)):

$$
S E=\frac{\sqrt{\sum\left(y_{o}-\hat{y}_{o}\right)^{2} /(n-2)}}{\sqrt{\sum\left(x_{o}-\bar{x}\right)^{2}}}
$$


where $y_{o}$ is the value of the dependent variable for the observation $(o), \hat{y}_{o}$ is the estimated value of the dependent variable for observation (o), $x_{o}$ is the observed value of the independent variable (year), $\bar{x}$ is the average of the independent variable, and $n$ is the number of observations.

\section{Submit or recommend next manuscript to SCIRP and we will provide best service for you:}

Accepting pre-submission inquiries through Email, Facebook, LinkedIn, Twitter, etc.

A wide selection of journals (inclusive of 9 subjects, more than 200 journals)

Providing 24-hour high-quality service

User-friendly online submission system

Fair and swift peer-review system

Efficient typesetting and proofreading procedure

Display of the result of downloads and visits, as well as the number of cited articles

Maximum dissemination of your research work

Submit your manuscript at: http://papersubmission.scirp.org/ 